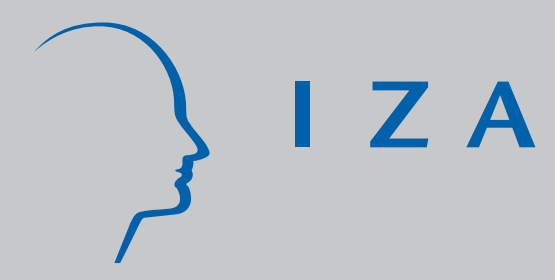

IZADP No. 1028

Education, Governance and Trade-Related Technology Diffusion in Latin America

Maurice Schiff

Yanling Wang

February 2004 


\title{
Education, Governance and Trade-Related Technology Diffusion in Latin America
}

\author{
Maurice Schiff \\ World Bank and IZA Bonn
}

Yanling Wang

Carleton University

\section{Discussion Paper No. 1028 \\ February 2004}

\author{
P.O. Box 7240 \\ 53072 Bonn \\ Germany
}

Phone: +49-228-3894-0

Fax: +49-228-3894-180

Email: iza@iza.org

\begin{abstract}
Any opinions expressed here are those of the author(s) and not those of the institute. Research disseminated by IZA may include views on policy, but the institute itself takes no institutional policy positions.
\end{abstract}

The Institute for the Study of Labor (IZA) in Bonn is a local and virtual international research center and a place of communication between science, politics and business. IZA is an independent nonprofit company supported by Deutsche Post World Net. The center is associated with the University of Bonn and offers a stimulating research environment through its research networks, research support, and visitors and doctoral programs. IZA engages in (i) original and internationally competitive research in all fields of labor economics, (ii) development of policy concepts, and (iii) dissemination of research results and concepts to the interested public.

IZA Discussion Papers often represent preliminary work and are circulated to encourage discussion. Citation of such a paper should account for its provisional character. A revised version may be available on the IZA website (www.iza.org) or directly from the author. 
IZA Discussion Paper No. 1028

February 2004

\section{ABSTRACT}

\section{Education, Governance and Trade-Related Technology Diffusion in Latin America*}

This paper examines the impact on TFP of North-South trade-related technology diffusion in Latin America and the Caribbean (LAC). North-South R\&D flows are constructed based on industry-specific R\&D in the North, North-South trade patterns, and input-output relations in the South. The main findings are: (i) Education and governance raise the level of TFP directly; and (ii) education and governance also raise TFP through their interaction with foreign R\&D in R\&D-intensive industries. These results imply a) that potential virtuous growth cycles exist both in the level and in the growth of TFP, and b) that taking into account the interaction effects between trade, education and governance by reforming the policies simultaneously will have a greater impact on TFP.

JEL Classification: F10, I20, O30, O38, O54

Keywords: $\quad$ technology diffusion, trade, R\&D intensity, education, governance, Latin America

Corresponding author:

Maurice Schiff

Development Research Group

The World Bank

Mailstop No. MC3-303

1818 H. St. NW

Washington DC 20433

Tel.: +1 2024737963

Fax: +1 2025221159

Email: mschiff@worldbank.org

\footnotetext{
* The opinions expressed in this paper are those of the authors and do not necessarily reflect those of the World Bank, its Board of Directors or the governments they represent.
} 


\section{EDUCATION, GOVERNANCE AND TrADE-RELATED \\ TECHNOLOGY DifFUSION IN LATIN AMERICA}

\section{Introduction}

This paper aims to examine the international diffusion of technological knowledge in Latin America and the Caribbean (LAC). In principle, such diffusion can occur through various channels, including trade, FDI, licensing, access to scientific journals, the internet, and other sources of cross-border communication. The principal channels that have been studied are trade and FDI. This paper focuses on trade as a channel of technology diffusion, and examines the importance of education and governance.

The development of endogenous growth theory originated with the papers of Romer (1986, 1990) and Lucas (1988). These papers posit that the returns to the accumulation of knowledge capital (Romer) and human capital (Lucas) do not diminish at the aggregate level because of positive spillover effects, and that policies can have a permanent impact on the rate of economic growth. ${ }^{1}$

Grossman and Helpman (1991) extended the Lucas and Romer analysis by exploring endogenous growth theory in an open economy setting. The basic idea is that goods embody technological know-how and therefore countries can acquire foreign knowledge through imports. Coe and Helpman (1995) provide an empirical implementation of the open economy endogenous growth model. They construct an index of foreign $R \& D$ as the trade-weighted sum of trading partners' stocks of R\&D. The idea is that importing countries learn from the knowledge embedded in the inputs that they import. The authors find for a sample of developed countries that both domestic and 
'foreign' R\&D have a significant impact on total factor productivity (TFP), and that the latter increases with the general degree of openness of the economy and with openness towards the larger R\&D producing countries. ${ }^{2}$

Coe et al. (1997) examine the same issue for developing countries. They find that developing countries benefit more from foreign R\&D spillovers, the more open they are and the more skilled is their labor force. These findings provide support for the hypothesis that trade is an important mechanism through which knowledge and technological progress is transmitted across countries. Schiff et al. (2002) study the same issue at the industry level. They find that developing countries do benefit from foreign R\&D spillovers, and that R\&D-intensive industries mainly benefit from trade with the North, while low R\&D-intensive industries benefit mainly from trade with the South.

This paper builds on Schiff et al. (2002) by examining these issues at the industry level for Latin America and the Carribean (LAC). ${ }^{3}$ As is shown in Section 2 below, our measure of the stock of foreign R\&D obtained by an importing country at the industry level explicitly incorporates the production structure of the economy as reflected in the input-output relationships.

The main findings for Latin American and Caribbean countries are:

1. Education and governance raise the level of TFP directly in all industries, and through their interaction with foreign $R \& D$ in $R \& D$-intensive

\footnotetext{
${ }^{1}$ An excellent review of the origins of endogenous growth is Romer (1994).

${ }^{2}$ Keller (1998) argues that Coe and Helpman's finding on trade as a channel for R\&D spillovers is not entirely conclusive. Lumenga-Neso et al. (2001) show that Coe and Helpman's results do seem to hold once 'indirect' trade-related R\&D spillovers are taken into account.

${ }^{3}$ Keller (2002) did examine trade-related R\&D spillovers at the industry level for the G-7 countries and Sweden.
} 
industries. This interaction effect rises with the degree of openness of the economy.

2. These results imply that potential virtuous growth cycles exist: an increase in education and/or governance raises TFP, especially in R\&D-intensive industries. This raises the demand for and level of education and/or governance, further raising TFP, and so on.

3. The level of these virtuous growth cycles rises with the degree of openness of the economy.

4. Given the growth of R\&D in OECD countries, an increase in education and/or governance raises TFP growth and may result in a virtuous cycle in the growth of TFP.

The remainder of the paper is organized as follows. Section 2 sets forth the empirical implementation, Section 3 presents the results and Section 4 concludes.

\section{Empirical Implementation}

Schiff et al. (2002) specify the following estimation equation:

$$
\log T F P_{c i t}=\alpha+\beta_{f} \log R D_{c i t}^{f}+\delta X+\varepsilon_{c i t} ; \beta_{f}>0
$$

where $R D_{\text {cit }}^{f}$ is the foreign $\mathrm{R} \& \mathrm{D}$ stock, $\varepsilon$ is an error term, $\mathrm{X}$ is vector containing some other variables of interest, and c (i) (t) denotes country (industry) (year). Due to lack of data, domestic R\&D is not included in that paper. However, this is unlikely to be a major problem because most of the world's R\&D is performed in developed countries. ${ }^{4}$

\footnotetext{
${ }^{4}$ In 1990, 96\% of the world's R\&D expenditures took place in industrial countries (Coe et al., 1997). Moreover, recent empirical work has shown that much of the technical change in OECD countries is based on the international diffusion of technology among OECD countries. For instance, Eaton and Kortum
} 
We estimate TFP equations with pooled data for a panel of twenty five countries and sixteen industries over a twenty three year period. The stock of foreign $R \& D$ available in industry $\mathrm{i}$ of developing country $\mathrm{c}, N R D_{c i}$, is defined as:

$$
N R D_{c i} \equiv \sum_{j} a_{c i j} R D_{c j}=\sum_{j} a_{c i j}\left[\sum_{k}\left(\frac{M_{c j k}}{V A_{c j}}\right) R D_{j k}\right],
$$

where $\mathrm{c}(\mathrm{k})$ indexes developing (OECD) countries, $\mathrm{j}$ indexes industries, $\mathrm{M}(\mathrm{VA})(\mathrm{RD})$ denotes imports (value added) (R\&D), and $a_{c i j}$ is the import input-output coefficient (which measures for country $\mathrm{c}$ the share of imports of industry $\mathrm{j}$ that is sold to industry $i$ ).

The first part of equation (2) says that, in developing country c, foreign R\&D in industry $\mathrm{i}, N R D_{c i}$, is the sum, over all industries $\mathrm{j}$, of $R D_{c j}$, the industry-j R\&D obtained through imports from OECD countries, multiplied by $a_{c i j}$, the share of imports of industry $\mathrm{j}$ that is sold to industry $\mathrm{i}$. The second part of equation (2) says that $R D_{c j}$ is the sum, over OECD countries $\mathrm{k}$, of $M_{c j k} / V A_{c j}$, the imports of industry-j products from OECD country k per unit of industry-j value added (i.e., the bilateral openness share), multiplied by $R D_{j k}$, the stock of industry-j R\&D in OECD country $\mathrm{k}$.

We also examine the impact of education and governance. We would expect education and governance to have a positive effect on TFP. A higher level of education implies a more productive labor force and a higher level of TFP. And a higher quality of governance (e.g., laws for and enforcement of property rights and contracts) creates new opportunities by lowering the cost of doing business, promoting entrepreneurial activity

(1999) estimate that $87 \%$ of French growth is based on foreign R\&D. Since developing countries invest much fewer resources in R\&D than OECD countries, foreign R\&D must be even more important for developing countries as a source of growth. 
and a greater division of labor and specialization. This results in a higher TFP. The estimated equation is:

$\log T F P_{c i t}=\beta_{0}+\beta_{N} \log N R D_{c i t}+\beta_{E} E_{c t}+\beta_{G} G_{c t}+\sum \beta_{t} D_{t}+\sum \beta_{c} D_{c}+\sum_{i} \beta_{i} D_{i}+\varepsilon_{c i t}$, (3) where $E(G)$ denotes education (governance), and $D_{t}\left(D_{c}\right)\left(D_{i}\right)$ represents time (country) (industry) dummies.

As in Schiff et al. (2002), we further examine how the impact of NRD varies with industries' R\&D intensity. We divide the industries into two groups according to their R\&D intensity.

$$
\begin{aligned}
\log T F P_{c i t}=\beta_{0}+ & \left(\beta_{N}+\gamma_{N} D R\right) \log N R D_{c i t}+\beta_{E} E_{c t}+\beta_{G} G_{c t} \\
& +\sum_{t} \beta_{t} D_{t}+\sum_{c} \beta_{c} D_{c}+\sum_{i} \beta_{i} D_{i}+\varepsilon_{c i t},
\end{aligned}
$$

where $\mathrm{DR}=1(0)$ for high (low) R\&D-intensity industries. We also estimate equation (4) with DR replacing the industry dummies $D_{i}$.

Our sample consists of nine Latin American and Caribbean (LAC) countries and sixteen other developing countries. The parameters for the LAC countries are estimated as differences from the parameters for the entire sample of developing countries in equations (3) and (4). Thus, equation (3) becomes:

$$
\begin{aligned}
\log T F P_{c i t}= & \beta_{0}+\left(\beta_{N}+\alpha_{N} D L A C\right) \log N R D_{c i t}+\left(\beta_{E}+\alpha_{E} D L A C\right) E_{c t} \\
& +\left(\beta_{G}+\alpha_{G} D L A C\right) G_{c t}+\sum_{t} \beta_{t} D_{t}+\sum_{c} \beta_{c} D_{c}+\sum_{i} \beta_{i} D_{i}+\varepsilon_{c i t}
\end{aligned}
$$

and equation (4) becomes:

$$
\begin{aligned}
\log \text { TFP }_{c i t}= & \beta_{0}+\left[\beta_{N}+\alpha_{N} D L A C+\left(\gamma_{N}+\delta_{N} D L A C\right) D R\right] \log N R D_{c i t} \\
& +\left[\beta_{E}+\alpha_{E} D L A C+\left(\gamma_{E}+\delta_{E} D L A C\right) D R\right] E_{c t} \\
& +\left[\beta_{G}+\alpha_{G} D L A C+\left(\gamma_{G}+\delta_{G} D L A C\right) D R\right] G_{c t} \\
& +\sum_{t} \beta_{t} D_{t}+\sum_{c} \beta_{c} D_{c}+\sum_{i} \beta_{i} D_{i}+\varepsilon_{c i t}
\end{aligned}
$$


Finally, we also examine the interaction between education or governance (or both) and NRD to see if the former affect TFP not just directly but also by affecting the impact of NRD on TFP. Thus, equation (6) becomes

$$
\begin{aligned}
\log T_{F P} P_{c i t}= & \beta_{0}+\left[\beta_{N}+\alpha_{N} D L A C+\left(\gamma_{N}+\delta_{N} D L A C\right) D R\right] \log N R D_{c i t} \\
& +\left[\beta_{N}^{\prime}+\alpha_{N}^{\prime} D L A C+\left(\gamma_{N}^{\prime}+\delta_{N}^{\prime} D L A C\right) D R\right] E_{c t} \log N R D_{c i t} \\
& +\left[\beta_{E}+\alpha_{E} D L A C+\left(\gamma_{E}+\delta_{E} D L A C\right) D R\right] E_{c t} \\
& +\left[\beta_{G}+\alpha_{G} D L A C+\left(\gamma_{G}+\delta_{G} D L A C\right) D R\right] G_{c t} \\
& +\sum_{t} \beta_{t} D_{t}+\sum_{c} \beta_{c} D_{c}+\sum_{i} \beta_{i} D_{i}+\varepsilon_{c i t},
\end{aligned}
$$

or with $G_{c t} \log N R D_{c i t}$ or $E_{c t} G_{c t} \log N R D_{c i t}$ replacing $E_{c t} \log N R D_{c i t}$ in the interaction term of equation (7).

Our sample consists of 16 manufacturing industries in the 9 LAC countries being examined as well as in the other developing countries in our sample, over the period 1976-98, with 15 OECD trading partners. ${ }^{5}$ The definitions of variables and data sources for TFP, education, import, value added, and the input-output matrices are documented in Schiff et al. (2002). The 9 LAC countries are Bolivia, Chile, Colombia, Ecuador and Venezuela in South America; Guatemala, Mexico and Panama in the rest of Latin America; and Trinidad and Tobago in the Caribbean. ${ }^{6}$

The sixteen industries were divided into two groups: six R\&D-intensive industries and ten low R\&D-intensity industries. ${ }^{7}$ The R\&D intensity of the sixteen industries is

\footnotetext{
${ }^{5}$ The 15 OECD countries are: Australia, Canada, Denmark, Finland, France, Germany, Ireland, Italy, Japan, Netherlands, Norway, Spain, Sweden, United Kingdom, and United States.

${ }^{6}$ The other 16 developing countries are in East Asia (Hong Kong, Korea Rep.), South Asia (Bangladesh, India, Pakistan), South-East Asia (Indonesia, Malaysia, Philippines), Middle East (Egypt, Iran, Jordan, Kuwait), Sub-Saharan Africa (Cameroon, Malawi), and Europe (Cyprus, Poland).

7 The six R\&D-intensive industries are: (1) 382-Non-Electrical Machinery, Office \& Computing Machinery; (2) 383-Electrical Machinery and Communication Equipment; (3) 384-Transportation Equipment; (4) 385-Professional Goods; (5) 351/2-Chemicals, Drugs \& Medicines; and (6) 353/4Petroleum Refineries \& Products. The ten low R\&D-intensity industries are: (1) 31-Food, Beverage \& Tobacco; (2) 32-Textiles, Apparel \& Leather; (3) 33-Wood Products \& Furniture; (4) 34-Paper, Paper Products \& Printing; (5) 355/6-Rubber \& Plastic Products; (6) 36-Non-Metallic Mineral Products; (7) 371Iron \& Steel; (8) 372-Non-Ferrous Metals; (9) 381-Metal Products; and (10) 39-Other Manufacturing.
} 
based on US data. An industry's R\&D intensity was calculated as R\&D expenditures divided by the value added of that industry. The average R\&D intensity in the "high" group is $11 \%$ or more than 8 times of the $1.3 \%$ "low" group.

As for governance, six measures and an average of the six measures are used. These were aggregated from a data base consisting of hundreds of variables, and range from -2.5 to +2.5 (Kaufmann, Kraay and Zoido-Lobaton, 1999a, 1999b). The range is smaller in our sample because it excludes industrial countries and many least developed countries. The (simple) average of the six measures is shown in Table A.1. ${ }^{8}$

\section{Estimation Results}

\subsection{Primary Regression Results}

The results for equations (3) - (7) are reported in Tables 1, 2 and 3. Table 1 presents industry-level results for the entire sample of 25 developing countries. The first regression shows that NRD (foreign R\&D) has a positive impact on TFP, with an elasticity of .188 . The second regression shows an elasticity of TFP with respect to foreign R\&D of .138 for the low R\&D-intensity industries and of .273 $(.138+.135)$ for the R\&D-intensive industries. Thus, the South obtains productivity gains by trading with the North and significantly more so in R\&D-intensive industries than in low R\&Dintensity industries. All results are significant at the $1 \%$ level.

\footnotetext{
${ }^{8}$ The first measure is "voice and accountability", a measure of the openness of the political process, civil liberties and political rights; the second one measures "political instability and violence"; the third one measures "government effectiveness," and includes the independence of the civil service from political pressures and the credibility of governments' policy commitment; the fourth one is the "regulatory burden," and includes the incidence of price controls and perceptions of burdens from excessive trade and business regulations; the fifth one is the "rule of law," including enforceability of contracts, crime incidence, and effectiveness of the judiciary; and the sixth is "graft" and measures perceptions of corruption.
} 
The effect of education (E) on TFP is positive in both regressions and significant at the $1 \%$ level. As for governance, the variable $(\mathrm{G})$ used in the regression is a simple average of the six governance measures described in Section 2. The results show that governance has a positive and significant impact on TFP (at the $5 \%$ level). The estimation results with the six individual governance measures are provided at the bottom of Table 1. For these regressions, we only show the governance results because those for the other variables are very similar to the results obtained with the average measure. All the coefficients for the individual governance measures are positive and significant at either the $1 \%$ or $5 \%$ level.

Table 2 presents estimation results for LAC. Regressions (iii) and (iv) are obtained by adding dummy variables to regressions (i) and (ii) for the LAC countries. Equation (iii) shows some surprising results. The elasticity of foreign R\&D for non-LAC developing countries is .245 , while that for LAC is .020 and is not significantly different from zero. On the other hand, the effect of education is $18.07(4.59+13.48)$ for LAC, or four times larger for LAC than for non-LAC countries. As for governance, the effect is $3.24(.65+2.59)$ in LAC or five times larger than in non-LAC countries.

Equation (iv) shows similar results to those of equation (iii). For low R\&Dintensity industries $(\log N R D$ and $\log N R D * D R * D L A C)$, the elasticity of foreign R\&D is .257 for non-LAC countries and negative but not significant $(t=1.58)$ for LAC countries. For R\&D-intensive industries $\left(\log N R D^{*} \mathrm{DR}\right.$ and $\left.\log \mathrm{NRD} * \mathrm{DR} * \mathrm{DLAC}\right)$, the elasticity is $.342(.257+.085)$ for non-LAC countries and $.020(.342-.350+.028)$ for LAC countries. Thus, the direct impact of foreign R\&D on TFP in LAC is not significantly different from zero. 
These results indicate that the direct impact of the North's R\&D on TFP is much smaller in LAC countries, but the effect of education and governance on TFP is several times larger than in non-LAC developing countries. One reason for the higher elasticity of TFP with respect to education and governance in LAC countries may be that both are smaller in those countries. The average education level in 1998 is $9.55 \%$ in LAC countries and $14.75 \%$ in non-LAC countries. A similar point is made by Maloney (2002). The corresponding figures for governance are -.075 and .078 .

These results may also signal potential interaction effects in LAC, with the education and governance variables capturing some of the effects of foreign R\&D. This is examined in Table 3 where we introduce interaction effects between foreign $R \& D$, on the one hand, and education, governance or both, on the other.

\subsection{Interaction with Education}

In equation (v) in Table 3, education is interacted with foreign R\&D in R\&Dintensive industries $(\log \mathrm{NRD} * \mathrm{DR} * \mathrm{E}$ and $\log \mathrm{NRD} * \mathrm{DR} * \mathrm{DLAC} * \mathrm{E}) .{ }^{9}$ The interaction effect for non-LAC countries is negative (-.068) but not significant, while the interaction effect for LAC countries is .206 (.274 - .068) and significant at the 5\% level. Thus, though the direct effect of foreign $\mathrm{R} \& \mathrm{D}$ is much smaller in LAC countries than in nonLAC ones, the interaction effect between foreign $R \& D$ and education is positive for R\&D-intensive industries in LAC but not in non-LAC countries. These results seem to confirm Maloney's (2002) point that because LAC pursued inward-oriented policies, it absorbed relatively little knowledge from OECD countries, and that potential knowledge

\footnotetext{
${ }^{9}$ We also included the variables $\mathrm{E}^{*} \mathrm{DR}$ and $\mathrm{D} * \mathrm{DLAC}$, but they were both found to be non-significant.
} 
absorption benefits could be obtained through increased spending on human capital and scientific infrastructure.

The fact that the direct impact of foreign R\&D on TFP is not significant in LAC countries does not imply that the total effect of foreign R\&D on TFP is small, at least as far as R\&D-intensive industries are concerned. With an average education level of $9.55 \%$ in LAC countries in 1998, the elasticity of TFP with respect to NRD in R\&D-intensive industries is $1.97\left(.206^{*} 9.55\right)$, several times larger than the elasticity of $.350(.247+.103)$ in non-LAC countries

We also tried interaction effects between education and foreign R\&D for low R\&D-intensity industries but these turned out not to be significant. This should not be surprising. Education reflects the capacity of the LAC countries to absorb knowledge from the North and transform it into higher productivity. And absorptive capacity is clearly more important in R\&D-intensive industries than in low R\&D-intensity industries.

What does this imply for the effect of education on TFP in LAC? $\partial \log T F P / \partial E$ $=5.778+.206 \log N R D * D R$. The average value of $\log N R D$ for the R\&D-intensive industries in LAC is 25 . Thus, a 1 percentage point increase in education raises TFP by $5.778 \%$ in low R\&D-intensity industries, and by $5.778+5.15(=5.778+.206 * 25)$ or $10.93 \%$ in R\&D-intensive industries. In other words, a one percentage point increase in the level of education raises TFP almost twice as much in R\&D-intensive industries as in low R\&D-intensity industries.

In fact, the difference between the two effects is even larger. The reason is that education and TFP have mutually reinforcing effects in R\&D-intensive industries, 
implying a potential virtuous growth cycle for the level of TFP in LAC. The mechanism is as follows. An increase in education raises TFP in all industries but it raises TFP in R\&D-intensive industries by close to $90 \%$ more. The relative increase in the productivity of R\&D-intensive industries raises the demand for skilled labor (relative to unskilled labor) which is used intensively in these industries and is complementary with technology. This leads to further--possibly private--investments in education, further increases in the TFP of R\&D-intensive industries (by $90 \%$ more than in low R\&Dintensity industries), further increase in the demand for skilled labor, and so on.

An increase in openness raises the level of foreign R\&D. In the case of R\&Dintensive industries in LAC, foreign R\&D interacts positively with education, with an effect on TFP of .206. This implies that the positive impact of education on TFP in R\&Dintensive industries in LAC rises with the degree of openness, and so does the impact of openness on TFP growth in the virtuous growth cycle. Moreover, an increase in the degree of openness raises the impact of education on TFP, raises the demand for education, raising TFP again, and thus also results in a virtuous growth cycle.

So far, we have abstracted from the growth of R\&D stocks in the OECD. As R\&D stocks in OECD countries increase over time, foreign $R \& D$ in all industries, including in R\&D-intensive industries in LAC, rises as well. Assume that foreign R\&D rises at a rate "g" per year in R\&D-intensive industries because of the increase in OECD R\&D stocks. This has an impact on the growth of TFP equal to $g^{*}(.206) * E$ (see equation (v)). Thus, the growth rate of TFP in R\&D-intensive industries in LAC rises with education. In other words, growth of technological knowledge in the North translates into higher growth rates in the $\mathrm{R} \& \mathrm{D}$-intensive industries in LAC when the absorptive capacity 
(i.e., the education level) is higher. Thus, education can have a permanent effect on TFP growth in R\&D-intensive industries in LAC, and - as with the level of TFP--it can have a virtuous-cycle effect on TFP growth.

\subsection{Interaction with Governance}

We now turn to equation (vi). That equation is similar to equation (v) except that interaction effects are with respect to governance rather than with education. ${ }^{10}$ Governance also interacts positively and significantly with foreign knowledge in LAC's R\&D-intensive industries, with a coefficient equal to $.015(.033-.018)$.

The effect of governance on TFP in R\&D-intensive industries in LAC is $\partial \log T F P / \partial G=.798+.015 \log N R D$. With an average value for $\log \mathrm{NRD}$ in R\&Dintensive industries in LAC equal to 25 , the effect is equal to .798 in low R\&D-intensity industries and $.798+.375=1.173$ in R\&D-intensive industries.

Note that a virtuous growth cycle may be present here as well. An improvement in the quality of governance raises TFP in all industries, though more so in R\&D-intensive industries. The higher productivity raises the value of good governance, including the rule of law (enforceability of contracts, respect for property rights, effectiveness of the judiciary), political stability, credibility of policy commitments, and incidence of corruption. ${ }^{11}$ The greater benefit of good governance raises the demand for governance, and is thus likely to raise its equilibrium level. This has a further positive impact on TFP, which results in a further increase in the demand for governance, and so forth. Note also that this virtuous growth cycle is stronger for R\&D-intensive industries and that it rises

\footnotetext{
${ }^{10}$ As in column (v), we also included G*DR and G*DLAC in the regression equation, but they are both found to be non-significant.
} 
with the degree of openness of the economy. Moreover, an increase in openness may trigger a virtuous growth cycle by raising the impact of governance on TFP.

Finally, governance can have a permanent effect on TFP growth in R\&Dintensive industries. As R\&D grows in OECD countries over time, foreign R\&D grows as well. And the effect of the growth in foreign R\&D on TFP growth increases with the level of governance (see equation (vi)). And there may also be a virtuous cycle in the effect of governance on TFP growth.

\subsection{Interaction with Education and Governance}

Equation (vii) in Table 3 shows the interaction effect of education, governance and foreign $\mathrm{R} \& \mathrm{D}$ for $\mathrm{R} \& \mathrm{D}$-intensive industries in LAC. ${ }^{12}$ Once again, the results on education and governance presented above carry through, and the interaction effect is equal to .191 (.252 - .061). These results imply that increases in both education and governance have permanent effects on the level and growth of TFP and that these effects are mutually reinforcing. And the virtuous growth cycles are mutually reinforcing too.

Another implication is that, at least as far as R\&D-intensive industries in LAC are concerned, countries would benefit more by coordinating reforms in education, governance and trade policy, than by focusing on each policy individually.

\section{Conclusion}

Recent theoretical models of economic growth have highlighted the importance of trade as a channel of technology diffusion. Empirical studies of the impact of North-

\footnotetext{
${ }^{11}$ Since governance has a constant percentage effect on TFP, its absolute effect rises with governance.
} 
South trade-related technology diffusion on total factor productivity (TFP) have been undertaken at the aggregate level. This paper examines this issue at the industry level. It also examines the impact of education and governance on TFP.

We find that North-South technology diffusion (foreign R\&D) has a large direct impact on TFP in non-LAC countries but no significant impact on TFP in LAC countries. On the other hand, we find for R\&D-intensive industries that both education and governance interact positively with foreign R\&D (in their effect on TFP) in LAC countries. This implies that an increase in education and/or governance has a permanent effect on TFP growth in LAC's R\&D-intensive industries. It also implies that increases in openness, education and/or governance are likely to generate virtuous growth cycles in both the level and growth of TFP.

\section{References}

Coe, David T., and Elhanan Helpman and Alexander W. Hoffmaister, "North-South R\&D Spillovers", Economic Journal 107, 1997: 134-149.

Coe, David T., and Elhanan Helpman, "International R\&D Spillovers." European Economic Review 39 (5), 1995: 859-887.

Grossman, M. Gene, and Elhanan Helpman, "Innovation and Growth in the Global Economy." Cambridge, MA: London, The MIT Press, 1991.

Kaufmann, Daniel, A. Kraay and P. Zoido-Lobaton, "Aggregating Governance Indicators." World Bank Policy Research Working Paper No. 2195. Washington. www.worldbank.org/wbi/governance, 1999(a).

Kaufmann, Daniel, A. Kraay and P. Zoido-Lobaton, "Governance Matters." World Bank Policy Research Working Paper No. 2196. Washington. www.worldbank.org/wbi/governance, 1999(b).

Keller, Wolfgang, "Are International R\&D Spillovers Trade-related? Analyzing Spillovers among Randomly Matched Trade Partners." European Economic Review 42,1998: 14691481.

Keller, Wolfgang, "Trade and the Transmission of Technology." Journal of Economic Growth 7, 2002: 5-24.

\footnotetext{
${ }^{12}$ Once again, we also included $\mathrm{E}^{*} \mathrm{G}^{*} \mathrm{DR}$ and $\mathrm{E}^{*} \mathrm{G}^{*} \mathrm{DLAC}$ in the regression equation, and they were found not to be significant.
} 
Lucas, Robert Jr., "On the Mechanics of Economic Development." Journal of Monetary Economics 22 (1), 1988: 3-42 (July).

Lumenga-Neso, Marcelo Olarreaga and Maurice Schiff, “On 'Indirect' Trade-Related Research and Development Spillovers." World Bank Policy Research Working Paper No. 2580 (April 2001). www.worldbank.org/research/trade.

Maloney, William, "Technology, Growth, and Resource Abundance." Mimeo, World Bank, 2002.

Romer, Paul M, “Increasing Returns and Long-Run Growth.” Journal of Political Economy 94 (5), 1986: 1002-37.

Romer, Paul M, "The Origins of Endogenous Growth." Journal of Economic Perspectives 8 (1), 1994: 3-22.

Romer, Paul M, “Endogenous Technical Change.” Journal of Political Economy 98, 1990:S71S102.

Schiff, Maurice, Wang, Y. and Olarreaga, M. "Trade-Related Technology Diffusion and the Dynamics of North-South and South-South Integration", World Bank Policy Research Working Paper \# 2861, 2002. ww.worldbank.org/research/trade. 
Table 1. Determinants of $\log$ TFP

(All developing countries)

\begin{tabular}{|c|c|c|}
\hline Variables & (i) & (ii) \\
\hline LnNRD & $\begin{array}{c}0.188 \\
(6.11)^{* * * *}\end{array}$ & $\begin{array}{c}0.138 \\
(4.08) * * *\end{array}$ \\
\hline $\operatorname{lnNRD*DR}$ & & $\begin{array}{c}0.135 \\
(3.41)^{* * * *}\end{array}$ \\
\hline $\mathbf{E}$ & $\begin{array}{c}6.752 \\
(4.3) * * *\end{array}$ & $\begin{array}{l}6.740 \\
(4.3) * * *\end{array}$ \\
\hline G & $\begin{array}{c}0.539 \\
(2.03) * *\end{array}$ & $\begin{array}{c}0.563 \\
(2.12) * *\end{array}$ \\
\hline Adjusted $\mathbf{R}^{2}$ & 0.2311 & 0.2325 \\
\hline No. of Observations & 5822 & 5822 \\
\hline Voice & $\begin{array}{c}1.756 \\
(7.91)^{* * *}\end{array}$ & $\begin{array}{c}1.735 \\
(7.82) * * *\end{array}$ \\
\hline $\begin{array}{l}\text { Political } \\
\text { Instability }\end{array}$ & $\begin{array}{c}0.565 \\
(2.03) * *\end{array}$ & $\begin{array}{c}0.590 \\
(2.12) * *\end{array}$ \\
\hline $\begin{array}{l}\text { Government } \\
\text { Effectiveness }\end{array}$ & $\begin{array}{c}0.411 \\
(2.03) * *\end{array}$ & $\begin{array}{c}0.430 \\
(2.12) * *\end{array}$ \\
\hline Burden & $\begin{array}{c}0.828 \\
(2.49) * *\end{array}$ & $\begin{array}{c}0.875 \\
(2.63) * * *\end{array}$ \\
\hline Rule of Law & $\begin{array}{c}0.329 \\
(2.03) * *\end{array}$ & $\begin{array}{c}0.344 \\
(2.12) * *\end{array}$ \\
\hline Graft & $\begin{array}{c}0.356 \\
(2.65) * * *\end{array}$ & $\begin{array}{c}0.353 \\
(2.62) * * *\end{array}$ \\
\hline
\end{tabular}

Note: Figures in parentheses are t-statistics. Significance levels of 1\% and 5\% are indicated by $* * *$ and $* *$ respectively. Regression results on country, year and industry dummies, and the constant, are not reported. NRD is the trade-related North-foreign R\&D. DR $=1$ for R\&D-intensive industries and $D R=0$ for low $R \& D$-intensity industries. $E$ is the secondary school completion ratio for the population aged $25+$. G is the average of six governance indicators: Voice, Political Instability, Government Effectiveness, Burden, Rule of Law, and Graft. 
Table 2. Determinants of $\log$ TFP with Latin America

\begin{tabular}{|c|c|c|}
\hline Variables & (iii) & (iv) \\
\hline LnNRD & $\begin{array}{c}0.245 \\
(7.39)^{* * *}\end{array}$ & $\begin{array}{c}0.257 \\
(6.50) * * *\end{array}$ \\
\hline $\operatorname{lnNRD*DLAC}$ & $\begin{array}{c}-0.225 \\
(-4.46) * * *\end{array}$ & $\begin{array}{c}-0.350 \\
(-6.03) * * * *\end{array}$ \\
\hline $\operatorname{lnNRD*DR}$ & & $\begin{array}{c}0.085 \\
(2.05)^{* *}\end{array}$ \\
\hline $\ln N R D * D R * D L A C$ & & $\begin{array}{c}0.028 \\
(3.80) * * *\end{array}$ \\
\hline $\mathbf{E}$ & $\begin{array}{c}4.587 \\
(2.83) * * *\end{array}$ & $\begin{array}{c}3.979 \\
(2.45)^{* *}\end{array}$ \\
\hline $\mathbf{E}^{*} \mathbf{D L A C}$ & $\begin{array}{c}13.481 \\
(3.48)^{* * * *}\end{array}$ & $\begin{array}{c}14.771 \\
(3.81)^{* * *}\end{array}$ \\
\hline G & $\begin{array}{c}0.65 \\
(3.22)^{* * *}\end{array}$ & $\begin{array}{c}0.665 \\
(3.25) * * *\end{array}$ \\
\hline G*DLAC & $\begin{array}{r}2.589 \\
(1.90) *\end{array}$ & $\begin{array}{c}5.484 \\
(3.54) * * * \\
\end{array}$ \\
\hline Adjusted R2 & 0.2348 & 0.238 \\
\hline No. of Observations & 5822 & 5822 \\
\hline
\end{tabular}

Note: Figures in parentheses are t-statistics. Significance levels of $1 \%$, $5 \%$ and $10 \%$ are indicated by $* * *, * *$ and $*$ respectively. Regression results on country, year and industry dummies, and the constant, are not reported. NRD is the trade-related North-foreign R\&D. DR $=1$ for $\mathrm{R} \& D$-intensive industries and $\mathrm{DR}=0$ for low $\mathrm{R} \& \mathrm{D}$-intensity industries. $\mathrm{DLAC}=1$ for Latin America countries and $\mathrm{DLAC}=0$ for non-Latin America countries. E is the secondary school completion ratio for the population aged $25+. \mathrm{G}$ is the average of these six governance indicators described in Section 2. 
Table 3. Determinants of $\log$ TFP with Latin America and Interaction Effects

\begin{tabular}{|c|c|c|c|}
\hline Variables & (v) & (vi) & (vii) \\
\hline $\ln N R D$ & $\begin{array}{c}0.247 \\
(6.25)^{* * * *}\end{array}$ & $\begin{array}{c}0.248 \\
(6.29) * * *\end{array}$ & $\begin{array}{c}0.249 \\
(6.29) * * *\end{array}$ \\
\hline $\operatorname{lnNRD*DLAC}$ & $\begin{array}{c}-0.316 \\
(-5.52) * * *\end{array}$ & $\begin{array}{c}-0.311 \\
(-5.44) * * *\end{array}$ & $\begin{array}{c}-0.31 \\
(-5.42) * * * *\end{array}$ \\
\hline $\operatorname{lnNRD*DR}$ & $\begin{array}{c}0.103 \\
(2.38) * *\end{array}$ & $\begin{array}{c}0.095 \\
(2.26) * *\end{array}$ & $\begin{array}{c}0.096 \\
(2.25) * *\end{array}$ \\
\hline $\ln N R D * D R * E$ & $\begin{array}{l}-0.068 \\
(-1.59)\end{array}$ & --- & --- \\
\hline $\ln N R D * D R * G$ & --- & $\begin{array}{c}-0.018 \\
(-2.74) * * *\end{array}$ & --- \\
\hline $\ln N R D * D R * E * G$ & --- & --- & $\begin{array}{l}-0.061 \\
(-1.46)\end{array}$ \\
\hline $\ln N R D * D R * D L A C$ & $\begin{array}{r}-0.001 \\
(-0.06)\end{array}$ & $\begin{array}{c}0.021 \\
(2.89) * * *\end{array}$ & $\begin{array}{c}0.02 \\
(2.52) * *\end{array}$ \\
\hline $\ln N R D * D R * D L A C * E$ & $\begin{array}{c}0.274 \\
(1.98) * *\end{array}$ & -- & --- \\
\hline $\ln N R D * D R * D L A C * G$ & --- & $\begin{array}{c}\mathbf{0 . 0 3 3} \\
(2.7)^{* * * *}\end{array}$ & --- \\
\hline $\ln N R D^{*} D^{*} R^{*} \operatorname{DAC}^{*} \mathbf{E}^{*} \mathrm{G}$ & --- & --- & $\begin{array}{c}0.252 \\
(2.45)^{* *}\end{array}$ \\
\hline $\mathbf{E}$ & $\begin{array}{c}5.778 \\
(3.56)^{* * *}\end{array}$ & $\begin{array}{c}5.415 \\
(3.42) * * *\end{array}$ & $\begin{array}{c}5.698 \\
(3.58) * * * *\end{array}$ \\
\hline G & $\begin{array}{c}0.683 \\
(2.57) * *\end{array}$ & $\begin{array}{c}0.798 \\
(2.95) * * *\end{array}$ & $\begin{array}{c}0.706 \\
(2.64) * * *\end{array}$ \\
\hline Adjusted R2 & 0.2367 & 0.2373 & 0.2377 \\
\hline No. of Observations & 5822 & 5822 & 5822 \\
\hline
\end{tabular}

Note: Figures in parentheses are t-statistics. Significance levels of $1 \%$ and $5 \%$ are indicated by $* * *$ and $* *$ respectively. Regression results on country, year and industry dummies, and the constant, are not reported. NRD is the traderelated North-foreign $\mathrm{R} \& \mathrm{D}$. $\mathrm{DR}=1$ for $\mathrm{R} \& \mathrm{D}$-intensive industries and $\mathrm{DR}=0$ for low R\&D-intensity industries. DLAC $=1$ for Latin America countries and $\mathrm{DLAC}=0$ for non-Latin America countries. $\mathrm{E}$ is the secondary school completion ratio for the population aged $25+$. $G$ is the average of these six governance indicators described in Section 2. 
Table A.1. Education and Governance

\begin{tabular}{|c|c|c|c|}
\hline Region & Country & Education $^{1}(\%)$ & Governance $^{2}$ \\
\hline \multirow{9}{*}{$\begin{array}{l}\text { LAC } \\
\text { Countries }\end{array}$} & Bolivia & 6.2 & 0.018 \\
\hline & Chile & 15 & 0.874 \\
\hline & Colombia & 8.43 & -0.408 \\
\hline & Ecuador & 7.97 & -0.321 \\
\hline & Guatemala & 2.53 & -0.504 \\
\hline & México & 12.93 & -0.071 \\
\hline & Panama & 16.2 & 0.115 \\
\hline & Tobago. & 12.33 & 0.589 \\
\hline & Venezuela & 4.33 & -0.369 \\
\hline \multirow{16}{*}{$\begin{array}{l}\text { Other } \\
\text { Countries: }\end{array}$} & Bangladesh & 5.07 & -0.392 \\
\hline & Cameroon & 2.87 & -0.726 \\
\hline & Cyprus & 19.77 & 1.019 \\
\hline & Egypt & 11.53 & -0.15 \\
\hline & Hong Kong & 28.67 & 0.992 \\
\hline & India & 6.23 & 0.002 \\
\hline & Indonesia & 11.03 & -0.763 \\
\hline & Iran & 12.73 & -0.538 \\
\hline & Jordan & 16.43 & 0.332 \\
\hline & Korea, Rep. & 35.07 & 0.483 \\
\hline & Kuwait & 25.23 & 0.343 \\
\hline & Malawi & 1.33 & -0.174 \\
\hline & Malaysia & 23.57 & 0.511 \\
\hline & Pakistan & 8.23 & -0.594 \\
\hline & Philippines & 17.03 & 0.212 \\
\hline & Poland & 19.37 & 0.696 \\
\hline
\end{tabular}

1. Education stands for the secondary school completion ratio for the population aged $25+$ in 1998 .

2. Governance figure reported is the average of the six governance indicators described in Section 2. 